* Doutor em Direito Civil pela Universidade de São Paulo-USP; Mestrado em Direito Negocial pela Universidade Estadual de Londrina-UEL; Professor Adjunto da Universidade Estadual de Londrina e da Pontifícia Universidade Católica do Paraná nos cursos de graduação e pósgraduação; Advogado. E-mail: wagnermarquesi@uol.com.br

** Graduado em Direito pela Pontifícia Universidade Católica do Paraná; Especialista em Direito do Estado pela Universidade Estadual de Londrina; Advogado. E-mail: alessandrobontempi@ hotmail.com

\section{Morosidade Processual e a Responsabilidade Civil DO EsTADo}

\author{
Procedural Delays And The Civil Liability Of The \\ STATE
}

\section{Roberto Wagner Marquesi* Alessandro Bontempi**}

Como citar: MARQUESI, Roberto Wagner; BONTEMPI, Alessandro. Morosidade processual e a responsabilidade civil do estado. Revista do Direito Público, Londrina, v. 14, n. 1, p. 139-159, abr. 2019. DOI: 10.5433/1980-511X2019v14n1p139. ISSN: 1980-511X.

Resumo: Com a promulgação da Emenda Constitucional $n^{0} 45 / 2004$, foi incluído na Constituição Federal, no rol dos direitos fundamentais, a razoável duração do processo, cujo objetivo é alcançar celeridade no trâmite processual. Contudo, passados 13 anos da publicação da Emenda, essa celeridade ainda se encontra longe do razoável. Assim, neste trabalho, dois focos foram abordados. Primeiramente, busca-se na literatura nacional e no direito comparado o conceito de razoável duração do processo. Em seguida, destacam-se no ordenamento nacional e no estrangeiro as principais posições doutrinárias e jurisprudenciais acerca da responsabilização objetiva do Estado pelo não cumprimento da razoável duração do processo, além de teses contrárias a esta. Para demonstrar que a promessa constitucional ainda é uma distante realidade no Brasil, foram pesquisados dados que possibilitam estimar o tempo médio para baixa de um processo de conhecimento em primeira instância no Poder Judiciário brasileiro, e comparar estes dados com sistemas judiciais estrangeiros. Verificou-se que o tempo médio para baixa em primeira instância no Judiciário brasileiro é de 925 dias, na França a média é de 128 dias, Itália 200 dias, Alemanha 220 dias, Espanha 242 dias e Portugal 414 dias.

Palavras-Chave: Direito civil. Responsabilidade civil. Razoável duração do processo. Morosidade da justiça. 


\begin{abstract}
The enactment of the constitutional amendment $n^{\circ}$ $45 / 2004$ included in the list of fundamental rights of the Federal Constitution the principle of reasonable duration of the process, aiming to achieve faster dispute resolutions in court. However, 13 years after the publication of the Amendment, reasonable duration of the process has been far from reality. Thus, in this paper, two directions were taken. First, the concept of the reasonable duration of the process was sought in the national literature and in comparative law. Next, we highlighted domestic and international laws, important doctrines and jurisprudence regarding the State's liability in the non-compliance of the principle of reasonable duration of the process; whilst also analyzing other thesis in the opposite direction. In order to demonstrate that the constitutional promise is still a distant reality in Brazil, we investigated data that made it possible to estimate the average length of time needed to res judicata at court trials, comparing this data with the data from other countries. In conclusion, we verified that the average time length for the first instance in the Brazilian Judiciary is a total of 925 days, which is contrary to European nations: in France the average is 128 days, Italy is 200 days, Germany is 220 days, Spain is 242 days and Portugal is 414 days.
\end{abstract}

Key Words: Civil Law; Civil Liability; The Principle of Reasonable Duration for the Process; Delay on the Proceedings. 


\section{INTRODUÇÃO}

O problema da morosidade processual não é novidade do Estado moderno, mas constitui um problema antigo, que se arrasta há séculos em vários ordenamentos jurídicos.

É sabido que o Estado-Juiz, por vezes, acarreta grandes prejuízos aos jurisdicionados, levando estes a suportar o injusto ônus do deficiente funcionamento do Poder Judiciário.

Inicialmente prevaleceu a teoria da irresponsabilidade do Estado, determinando que este não responderia pelos seus atos, com fundamento em diversas teorias, como a de que o Rei não erra. Com o passar dos séculos "começaram a surgir brechas na teoria da irresponsabilidade estatal quando se estabeleceu que o Estado responderia por erros judiciários na esfera penal." (DERGINT, 1994, p. 12).

Paulatinamente, a responsabilidade do Estado passou a ser a regra e a irresponsabilidade a exceção, admitindo-se em alguns casos até mesmo a responsabilidade sem culpa.

Mais tarde, a ideia da responsabilidade do Estado pela demora processual começou a tomar corpo, sobretudo na Europa, onde, em alguns ordenamentos, foi editada lei infraconstitucional específica, como no caso da Itália (Legge Pinto).

Nesse contexto, em 2004, a Emenda Constitucional nº 45 acrescentou ao artigo $5^{\circ}$. o inciso LXXVIII, prevendo que "a todos, no âmbito judicial e administrativo, são assegurados a razoável duração do processo e os meios que garantam a celeridade de sua tramitação.” (BRASIL, 1988).

Também em 2004 foi assinado em Brasília o Pacto de Estado em favor de um Judiciário mais rápido e republicano, fundando-se na seguinte premissa:

Poucos problemas nacionais possuem tanto consenso no tocante aos diagnósticos quanto a questão judiciária. A morosidade dos processos judiciais e a baixa eficácia de suas decisões retratam o desenvolvimento nacional, desestimulam investimentos, proporcionam, propiciam a inadimplência, geram impunidade e solapam a crença dos cidadãos no regime democrático (CÂMARA DOS DEPUTADOS, 2004).

Por este Pacto, os chefes dos três Poderes da Republica comprometeram-se a realizar ações no sentido de alcançar a celeridade processual. A despeito disso, decorridos 13 anos da Emenda Constitucional $n^{\circ} 45$ e da assinatura do Pacto, embora haja melhorias, a duração razoável do processo ainda não se concretizou.

\section{INDETERMINAÇÃO DO CONCEITO DE RAZOÁVEL DURAÇÃO DO PROCESSO}

A questão do que seria o razoável tempo processual sempre foi negligenciada pelos doutrinadores nacionais, conforme adverte Luiz Guilherme Marinoni:

A questão do tempo do processo sempre foi negligenciada pela doutrina do processo civil, que chegou a vê-la com "cientificamente" não importante. Não 
obstante, um dos grandes desafios - talvez o maior - da processualística moderna é conciliar o direito à tempestividade da tutela jurisdicional com o tempo necessário aos debates entre os litigantes, à investigação probatória e ao amadurecimento da convicção judicial (MARINONI, 2007, p. 11).

$\mathrm{O}$ argumento que sempre justificou a negligência doutrinária repousa na dificuldade de se determinar qual seria o tempo processual razoável. "Devido à complexidade da vida e das lides processuais, o prazo razoável somente pode ser indicado caso a caso, mediante juízo de razoabilidade e ponderação." (KOEHLER, 2013, p. 89).

A doutrina começou a preocupar-se a partir da promulgação do Pacto de San José da Costa Rica, em que se procurou formar um conceito para a expressão.

Segundo Danielle Annoni:

A expressão prazo razoável, que visa regular a garantia do demandante de obter do Poder Judiciário uma resposta pronta e efetiva, ou seja, o direito de que seu processo termine logo e lhe forneça uma resposta condizente com o pedido formulado, encontra no direito internacional, diversos sinônimos. A expressão prazo tem origem na Convenção Europeia de Direitos Humanos que trata do tema em seu art. $6^{\circ}$ (ANNONI, 2006, p. 18).

Nessa mesma linha, o prazo razoável é atingido quando a prestação for atendida dentro do tempo considerado como "bom" pelas partes. Para Alexandre Freitas Câmera, "processo excessivamente lento é incapaz de promover justiça, pois justiça que tarda falha. De outro lado, porém, o processo excessivamente rápido gera insegurança, sendo impossível que produza resultados justos" (CÂMERA, 2012, p. 166).

É direito dos jurisdicionados a prestação em prazo razoável, contudo acelerar o processo não pode ser confundido com celeridade da cognição. Por outro lado, a morosidade acarreta insegurança jurídica e causa desconfiança quanto ao um Judiciário eficiente.

Então, a questão principal para conceituação de razoável duração do processo é o equilíbrio entre celeridade e segurança jurídica, embora a doutrina não tenha um conceito unívoco do que seja a razoável duração do processo, pois "o conceito não pode ser analisado apenas em parâmetros temporais, mas também os meios que sejam capazes de garantir o cumprimento dos prazos" (SCABORA, 2011, p. 23). Daí a necessidade de fixar critérios.

\section{CRITÉRIOS PARA DETERMINAÇÃO DA RAZOÁVEL DURAÇÃO DO PROCESSO NA CORTE EUROPEIA DE DIREITOS HUMANOS}

A morosidade processual também é motivo de queixas em diversos países europeus, o que levou vários jurisdicionados a encaminhar reclamações perante a Corte Europeia de Direitos Humanos (CEDH). Diante disso, o Tribunal Europeu analisou e elaborou critérios da razoável duração do processo adotando a "doutrina do não prazo". 
O posicionamento "jurisprudencial da Corte fixa três critérios objetivos para verificar a razoável duração do processo: complexidade da causa; comportamento das partes; atuação do órgão jurisdicional" (VALENTE, 2008, p. 26).

Vejam-se os três:

\subsection{A Complexidade da Causa}

A complexidade da causa constitui o critério inicial do CEDH. Tal critério justifica, em certos casos, a demora processual devido às particularidades da demanda, "podendo provir tanto dos fatos da causa como do direito aplicável à mesma" (KOEHLER, 2013, p. 95). A complexidade da causa desdobra-se em três aspectos: a complexidade fática, a complexidade do direito e a complexidade instrumental.

A complexidade fática surge pela natureza da demanda, devido a uma grande quantidade de fatos a serem provados, ou a densidade das questões no campo probatório. A complexidade jurídica, por sua vez, se relaciona ao Direito a ser aplicado no caso concreto, por ser de difícil interpretação de determinada norma jurídica. Por fim, a complexidade instrumental se refere a questões intrínsecas à prática dos atos processuais, como intimações de parte ou localização de testemunhas (FERREIRA, 2013, p. 91).

A complexidade da causa não é aceita pela CEDH como única justificativa para a morosidade processual, entendendo que cabe ao Estado se equipar melhor e ao Juiz se dedicar mais.

\subsection{Comportamento das Partes}

O comportamento das partes pode por vezes causar a morosidade processual, havendo três teorias que analisam o comportamento das partes: a subjetiva; a objetiva; a mista.

Pela teoria subjetiva, vale a intensão da parte, sendo considerada ilícita a atitude que prejudica ou não traz nenhuma vantagem.

Para a teoria objetiva, mesmo sem haver intenção de prejudicar, a parte abusa de seu direito, violando o princípio da boa-fé objetiva. Ao analisar o abuso do direito dos litigantes à luz da teoria da boa-fé objetiva, informa André Luiz Nicolitt:

O fato é que as partes poderão utilizar legitimamente todos os meios que o ordenamento processual põe à disposição. Tratando-se de matéria cível, o que se deve verificar é o abuso do direito e o intuito protelatório. [...] O que se sanciona é o comportamento deliberadamente abusivo das partes. [...] Na doutrina se afirma que se pode reconhecer como justificada a finalidade exclusivamente dirigida ao atraso do procedimento, o que se revelaria ilegítimo seria ampara-se da dilação produzida para denunciar ao direito fundamental à duração razoável do processo, vez que a dilação na hipótese foi consequência exclusiva do próprio ato (2006 apud FERREIRA, 2013, p. 59-60). 
Nesse passo, conforme Carlos Henrique Ramos, “constata-se que não é incomum a contribuição da parte para demora processual, uma vez que, em alguns casos, essa demora propicia um benefício, sendo conveniente que o processo não chegue ao seu término" (2008 apud FERREIRA, 2013, p. 91-92). Portanto, é permitido que ambas as partes utilizem de todos os recursos processuais, desde que não tenha o único objetivo de deliberadamente atrasar a solução da demanda.

Já pela teoria mista, “dever-se-ia observar objetivamente a intenção da parte, por meio de uma análise do procedimento usual dos homens - a contrariedade quanto à conduta do homem médio demonstraria a obrigação de indenizar em razão do dano processual" (FERREIRA, 2013, p. 91-92).

Ressalta-se no comportamento das partes que o principal é a observação da ética dos litigantes, a lealdade, dentro de todo o direito de ampla defesa, cujo objetivo é a pacificação do conflito.

A Corte de Cassação Italiana, conforme explica Franco Petroleti, "segue o posicionamento da Corte Europeia, identificando uma obrigação de colaboração das partes para uma rápida definição dos processos, recaindo a incumbência de zelar para isso exclusivamente sobre o Estado, que, se carente, deve responder pela própria ineficiência" (2005 apud KOEHLER, 2013, p. 99).

Em outras palavras, o atraso ocasionado pela parte contrária não pode ser exclusivamente atribuído ao Estado pela demora não razoável da demanda.

\subsection{Atuação do Órgão Jurisdicional}

A atuação do órgão jurisdicional deve ser entendida em sentido amplo, compreendendo juízes e demais autoridades intervenientes na demanda, compreendendo, ao lado da Administração Pública, todos os principais destinatários que têm a obrigação de garantir a razoável duração do processo. Assim, "caso o retardamento do processo seja imputável à conduta das autoridades públicas atuantes na lide, configura-se um dos elementos de constatação da lesão à garantia fundamental, isto porque a verificação da razoabilidade está centrada na atuação do Estado-juiz como um todo." (KOEHLER, 2013, p. 105).

A Corte de Cassação Italiana considerou que os auxiliares da Justiça não são unicamente os colaboradores do Juízo, mas também órgãos diversos, como as autoridades administrativas.

Segundo a Corte Europeia de Direitos Humanos:

Não é aceitável, por exemplo, o intervalo de dois anos entre duas audiências de instrução, ou o prazo de quatro anos entre a interposição da apelação e respectivamente seu julgamento. Esses períodos são chamados pela doutrina do Tribunal de tempos mortos sintomatologia característica da grave desorganização cartorária e falhas estruturais na Administração da Justiça (DALMOTTO, 2002, p. 173-174). 
Por fim, as dilações processuais indevidas podem advir tanto da omissão dos órgãos jurisdicionais, como de sua própria ação. Exemplo é o ato do magistrado que admite produção de prova desnecessária, provocando o temporal aumento do processo e impedindo a solução da demanda em prazo razoável.

\section{A EMENDA CONSTITUCIONAL N. 45/2004 E A POSITIVAÇÃO DO DIREITO À RAZOÁVEL DURAÇÃO DO PROCESSO}

Embora o Brasil já fosse signatário do Pacto de San José da Costa Rica, de 1969, prevendo o Pacto que todo preso tem direito à razoável duração do processo, somente em novembro de 1992, pelo Decreto 678, foi o Pacto promulgado no plano interno. A doutrina e a jurisprudência tentaram determinar o status que o Pacto deveria ter no ordenamento jurídico interno, tendo a questão sido resolvida pelo Supremo Tribunal Federal (STF) ao decidir que o Pacto possui natureza supralegal, ou seja, em plano inferior ao da Constituição Federal e acima do ordenamento infraconstitucional, fazendo concluir que o direito à razoável duração do processo já estava inserido no ordenamento nacional antes mesmo da EC 45. Assim, a inclusão do inciso LXXVIII ao artigo $5^{\circ}$. não fez mais do que alçar este direito fundamental a nível constitucional, não se chocando ao Pacto, mas coadunando-se a este.

O inciso LXXVIII do artigo $5^{\circ}$ ordena que "a todos, no âmbito judicial e administrativo, são assegurados a razoável duração do processo e os meios que garantam a celeridade de sua tramitação" (BRASIL, 1988).

Importante ressaltar que tal dispositivo, "além do princípio da tempestividade do processo em seu bojo, dá um comando ao Estado tanto no âmbito judicial quanto administrativo, para finalizar o processo num determinado tempo, e que este seja no mínimo razoável” (JOBIM, 2012, p. 91-92).

Luiz Guilherme Marinoni assim visualiza a problemática:

$\mathrm{O}$ direito à defesa, assim como o direito à duração razoável do processo, são direitos fundamentais. Após a Emenda Constitucional 45/2004, que acrescentou o inciso LXXVIII ao art. $5^{\circ}$ da Constituição Federal, o titular do direito de ação possui direito fundamental à duração razoável do processo e às técnicas necessárias para lhe outorgar celeridade. Portanto, o legislador infraconstitucional tem a obrigação de construir procedimentos que tutelam de forma adequada e tempestiva os direitos, assim como o dever de instruir técnicas processuais que, atuando interinamente no procedimento, permitam uma racional distribuição do tempo do processo (MARINONI, 2007, p. 20).

Assim, tem o Estado o dever de ter juízes suficientes para despachar qualquer processo no tempo legal ou razoável e ainda estrutura e meios administrativos adequados à prestação jurisdicional, além de prestações positivas do legislador. 
Importante verificar que, embora a EC 45 tenha inserido o princípio, até o momento não há fixação legislativa de qual seria o lapso temporal para a razoável duração, pois isso ensejaria responsabilidade do Estado pela sua intempestividade. Já, mantendo-se sem nenhuma positivação legislativa, basta ao Estado alegar insuficiência de recursos ou excesso de demandas para eximirse da responsabilização.

\section{CONSEQUÊNCIAS DO ARTIGO $5^{\circ}$ INCISO LXXVIII DA CF/88}

Atualmente, os princípios têm força normativa, podendo inclusive ser utilizado como um balizador de decisões judiciais, sendo superada a ideia que os princípios são meras sugestões ao Juiz.

O STF, acerca da razoável duração, vem aplicando o princípio na esfera processual penal, conforme observado no seguinte acórdão:

EMENTA: RECURSO ORDINÁRIO EM HABEAS CORPUS. ROUBO QUALIFICADO E ASSOCIAÇÃO CRIMINOSA. PRISÃO. EXCESSO DE PRAZO NO ENCERRAMENTO DA INSTRUÇÃO CRIMINAL CONFIGURADO [...]. 4. A razoável duração do processo não pode ser considerada de maneira isolada e descontextualizada das peculiaridades do caso concreto. Decorridos mais de 5 (cinco) anos da efetivação da prisão sem julgamento em primeiro grau, não se justifica, na hipótese, a manutenção da constrição cautelar do agente. 5. Recurso ordinário não provido, com concessão de ofício da ordem de habeas corpus, para colocação em liberdade do Recorrente, salvo se por outro motivo tiver que permanecer preso (BRASIL, 2015).

Há que se ressaltar que "a prisão cautelar só se mantém legítima quando do cumprimento da razoável duração do processo, tendo o STF consagrado o pensamento de que o excesso de prazo da custódia provisória leva à ilegalidade da segregação" (FERREIRA, 2013, p. 88).

O STJ aplicou o princípio da razoável duração negando provimento ao recorrente que pleiteava a nulidade de todo o processo por ofensa ao direito de defesa:

PROCESSUAL CIVIL. RECURSO ESPECIAL. CERCEAMENTO DE DEFESA. INOCORRÊNCIA. PRODUÇÃO DE PROVA TESTEMUNHAL EM MATÉRIA DE DIREITO TRIBUTÁRIO A RESPEITO DE FATOS OCORRIDOS HÁ DOZE ANOS. PROVAS DOCUMENTAIS SUFICIENTES. CÓPIA INTEGRAL DO PROCESSO ADMINISTRATIVO. APLICAÇÃO DO DIREITO FUNDAMENTAL À DURAÇÃO RAZOÁVEL DO PROCESSO (ART. 5 $5^{\circ}$, LXXVIII, CF). 1. Anulatória de débito fiscal em que se alega cerceamento de defesa. Prova testemunhal não produzida. 2. Não-ocorrência de violação do devido processo legal. Provas colhidas no processo suficientes para a decisão proferida no Tribunal local [...]. 5. Na apuração da verdade real dos fatos, o juiz não pode se olvidar da primazia da celeridade processual, que não é incompatível com o due process of law. A verdadeira tutela jurisdicional é aquela prestada em tempo razoável (art. $5^{\circ}$, LXXVIII, CF), regra de ouro que vale tanto 
para o autor, como para o réu. 6. Recurso Especial a que se nega provimento (BRASIL, 2007).

No caso acima, o STJ considerou suficientes as provas documentais e negou provimento ao recurso com fundamento na razoável duração do processo.

Contudo, atualmente, os Tribunais Superiores aplicam timidamente a razoável duração do processo em seus julgados, passando aos poucos a ser uma preocupação dos litígios, porque, estar o Judiciário em atraso com seu jurisdicionado, é o mesmo que dizer que o Estado está em falta grave e, se isso ocorre, deve ele indenizar o prejudicado.

\section{RAZOÁVEL DURAÇÃO DO PROCESSO NO DIREITO COMPARADO}

Analisam-se a seguir posicionamentos doutrinários e jurisprudenciais dos ordenamentos da Argentina, Espanha e Itália, no que diz respeito à celeridade processual, e se estes responsabilizam o Estado pela tardia prestação jurisdicional.

\subsection{Argentina}

A Corte Suprema de Justiça da Argentina (Corte Suprema de Justicia de la Nación) considera a duração razoável do processo como um direito de defesa, devendo ser inserido no corpo do devido processo legal. No Recurso Ordinário de Apelação B.789 XXXI a Corte Suprema considerou:

A garantia constitucional da defesa em juízo e o devido processo não se esgotam no cumprimento normal dos trâmites previstos nas leis adjetivas sem que se estenda à necessidade de obter uma rápida decisão que ponha fim aos conflitos e situações de incerteza, evitando, dentro dos limites do razoável e conforme as circunstâncias de cada caso, uma dispendiosa e eventualmente inútil atividade jurisdicional. (ARGENTINA, 1996 apud FERREIRA, 2013, p. 15).

Assim, considera a jurisprudência argentina que dilações desnecessárias, ainda que normais aos olhos da lei, prejudicam o direito de defesa, privando a parte da efetiva justiça. Explica Camille Gonçalves que a falta legislativa vem sendo preenchida pela jurisprudência argentina “com uso da interpretação extensiva do princípio constitucional do direito de defesa, podendo gerar a responsabilização do Estado quando há dilações desnecessárias retardando seu resultado e prejudicando as partes" (FERREIRA, 2013, p. 16). Tal entendimento vem sendo reiteradamente aplicado pela Corte Suprema argentina.

Em algumas províncias da Argentina, como a Província de Buenos Aires, "existe legislação específica sobre a razoável duração do processo, mas a legislação nacional argentina ainda não faz expressa menção, forçando a jurisprudência no sentido de suprir essa falta, com responsabilização do Estado quando essa dilação indevida causar danos as partes envolvidas" (FERREIRA, 2013, 
p. 13).

Por aí se vê que, no vizinho Estado, a demora na prestação jurisdicional tem sido debatida.

\subsection{Espanha}

A Constituição espanhola prevê em seu artigo 24 o direito à razoável duração do processo, vedando expressamente indevidas dilações.

Artigo 24. 1. Todas as pessoas têm direito a obter a tutela efetiva dos juízes e tribunas no exercício de seus direitos e interesses legítimos, sem que, em nenhum caso, possa haver indefesos. 2. Além disso, todos têm direito a um juiz ordinário predeterminado por lei, à defesa e à assistência de um advogado, a ser informado de todas as acusações contra eles, a um julgamento público, sem dilações indevidas e com todas as garantias, a utilizar os meios de provas pertinentes à sua defesa, a não testemunhar contra si mesmos, a não se confessar culpado e à presunção de inocência. ${ }^{1}$ (ESPANHA, 1978, tradução nossa).

Para o doutrinador espanhol José Antônio Tomé Garcia, a expressão dilações indevidas contido no artigo 24 são:

Delongas que se produzem no processo por inobservância dos prazos estabelecidos, por injustificados prolongamentos das etapas mortas que separam a realização de um ato processual de outro, sem subordinação a um lapso temporal previamente fixado, e, sempre, sem que aludidas dilações dependam da vontade das partes ou de seus mandatários (apud VIANA, 2007, p.107).

Para a jurisprudência do Tribunal Constitucional Espanhol, as limitações de recursos humanos e estruturais não isentam o Estado de prestar a tutela em tempo razoável.

Recurso interposto contra decisão do julgado Contencioso Administrativo de Madrid número 24, datado de 14 de junho de 2010 [...]. Em resumo, a recorrente alega que a instrução do processo sumário núm.144-2010, marcada para 16 de maio de 2012, não respeitou a razoável duração do processo [...]. A jurisprudência constitucional lembrou na STC 942008 de 21 de Julho, que as deficiências estruturais não justificam dilações processuais indevidas [...]. Conclui-se que foi violado neste caso o direito a um julgamento sem dilações indevidas (art. 24.2 CE) dada a data de dois anos que o Tribunal fixou a audiência de seu recurso contencioso administrativa (ESPANHA, 2014, tradução nossa).

No ordenamento jurídico espanhol, o direito a um julgamento sem dilações indevidas

1 Texto Original: Art. 24. 1. Todas las personas tienen derecho a obtener la tutela efectiva de los jueces y tribunale senel ejercicio de sus derechos e intereses legítimos, sin que, em ningún caso, pueda producir sein defensión 2. Asimismo, todos tienen derecho al juez ordinario predeterminado por laley, a la defensa y a la asistencia de letrado, a ser informados de la acusación formulada contra ellos, a um proceso público sin dilaciones indebidas y con todas lãs garantías, a utilizar los médios de prueba pertinentes para su defensa, a no declarar contra símismos, a no confesarse culpables y a la presunción de inocencia. la ley regulará los casos en que, por razón de parentesco o de secreto profesional, no se estará obligado a declarar sobre hechos presuntamente delictivos. 
decorre do próprio Texto Constitucional, considerando a jurisprudência espanhola haver direito a indenização em casos de morosidade indevida, "utilizando o Tribunal Constitucional Espanhol à apreciação das circunstâncias do processo; complexidade objetiva; atitude processual do recorrente; atitude dos órgãos judiciais e os meios disponíveis" (FERREIRA, 2013, p. 32).

Em relação aos dois últimos, vê-se na jurisprudência da Corte que as limitações humanas e estruturais não eximem uma condenação por dilações indevidas, ensejando responsabilidade civil do Estado.

Assim, para a Corte espanhola as dilações indevidas violam o direito fundamental. Veja-se:

Todo conjunto nos leva a acreditar que o prazo de inatividade do processo não foi justificado e por consequência não razoável (STC 1441995), porque no recurso de apelação foi ferido o direito fundamental a um processo sem dilações indevidas (art. 24.2 CE). Portanto, não sendo possível a restituição desse direito fundamental, deve-se converter para a via indenizatória (art.55.1 c LOTC). Assim, por todo o exposto, este Tribunal Constitucional, pela autoridade que lhe confere a Constituição da Nação Espanhola, decide acolher o presente recurso de ampara e em consequência: $1^{\circ}$ - Declarar que foi violado o direito fundamental do recorrente a um processo sem dilações indevidas, realizado pela Terceira Sala do Tribunal Supremo, no recurso de apelação referido. $2^{\circ}$ - Conferir à recorrente a integridade de seu direito mediante correspondente indenização a cargo do Estado $^{2}$ (ESPANHA, 1996, tradução nossa).

Aqui se tem exemplo de morosidade processual gerando pretensão indenizatória.

\subsection{Itália}

Um dos ordenamentos jurídicos mais estudados, devido ao posicionamento de seus juristas, é o ordenamento italiano. Contudo, embora o grande valor de seu sistema processual, a Itália ainda está às voltas com a delonga processual, conforme comenta José Carlos Barbosa Moreira:

$\mathrm{Na}$ área civil, segundo dados constantes do relatório sobre a administração da Justiça em 1988, elaborado pelo Procurador-Geral da República junto a Corte de Cassação, girou em torno de quatro anos, entre 1991 e 1997, a duração média de processos em primeiro grau de jurisdição, perante os órgãos de competência comum (MOREIRA, 2001, p.2).

\footnotetext{
2 Acórdão original: Todo ello nos mueve a estimar que "el plazo de inactividad procesal transcurrido no está justificado, siendo, en consecuencia, no razonable" (STC 1441995), por lo que en la tramitación del recurso de apelación de referencia se produjo vulneración del derecho fundamental a un proceso sin dilaciones indebidas (art. 24.2 C.E.). Ahora bien, no sien doposible la restitutio in integrum del derecho fundamental dado que el proceso ha fenecido, el restablecimiento, solicitado por la recurrente, en la integridad de su derecho con la adopción de las medidas apropiadas, en su caso, para su conservación (art. 55.1.c LOTC) solo podrá venir por la via indemnizatoria. En atención a todo lo expuesto, el Tribunal Constitucional, por la autoridad que le confiere la Constitución de la Nación Española ha decidido estimar el presente recurso de amparo y, en consecuencia:

$1^{\circ}$. Declarar que el derecho fundamental de la recurrente a un proceso sin dilaciones indebidas ha sido vulnerado en la tramitación realizada por la Sala Tercera del Tribunal Supremo del recurso de apelación de referencia.

$2^{\circ}$. Restablecer ala recurrente en la integridad de su derecho mediante la correspondiente indemnización, en su caso, a cargo del Estado.
} 
Para alterar este quadro, em 2001 foi inserido na Constituição italiana o artigo 111, prevendo expressamente a razoável duração do processo.

Ainda, devido às constantes condenações que a Itália sofreu por morosidade processual na Corte Europeia de Direitos Humanos, aliado à reposta do chamamento constitucional, o legislador italiano editou a Lei Pinto (Legge Pinto), prevendo indenização pelo descumprimento do prazo razoável na duração do processo. Seu artigo $2^{\circ}$. faz direta referência à Convenção Europeia dos Direitos do Homem.

Humberto Dalla Bernardina de Pinho explica que:

O advento da "Legge Pinto" no ordenamento italiano inova ao prever a reparação do dano causado pela excessiva duração do processo, reconhecendo o Estado que a entrega da prestação jurisdicional tardia, por si só, tem o condão de gerar um dano aos demandantes, reformando o artigo 375 do código de processo italiano. Prevê a responsabilidade e a obrigatoriedade do Estado pela indenização às partes, quando violada a garantia fundamental da razoável duração do processo, desde que estas não tenham concorrido para excessiva duração, ou mesmo, em decorrência da complexidade da matéria (2007 apud JOBIM, 2012, p.183, tradução nossa).

$\mathrm{O}$ artigo 2.1 dessa lei determina:

Quem sofreu um dano patrimonial ou extrapatrimonial como resultado da violação da Convenção para a Proteção dos Direitos do Homem e das Liberdades Fundamentais, ratificado nos termos da Lei 848 de 4 de agosto de 1955, em termos de não cumprimento do prazo razoável especificado no artigo $6^{\circ}, \& 1^{\circ}$ da Convenção, tem o direito a uma justa reparação"3 (ITÁLIA, 2001, tradução nossa).

Vários são os comandos da Lei Pinto, estabelecendo os valores de reparação, critérios de liquidação, comandos de caráter processual, etc.

Importante ainda apresentar o consolidado posicionamento jurisprudencial da Corte de Cassação Italiana no sentido de que "tanto o sucumbente quanto o vitorioso podem pleitear indenização por violação a razoável duração do processo, pois o direito de indenização espera a todas as partes do processo, ao menos que a parte vencida tenha promovido lide temerária ou resistido injustificadamente à jurisdição com o único propósito de buscar a indenização" (2010, apud FERREIRA, 2013, p. 58).

Devido às recentes alterações, a Itália conseguiu significativa redução na celeridade processual, passando de 4 anos para aproximadamente 200 dias o tempo de tramitação na primeira

3 Redação original: Chi há subito un danno patrimoniale o non patrimoniale per effetto di violazione della Convenzione per la salvaguardia dei diritti dell'uomo e delle libertá fondamentali, ratificata ai sensi della legge 4 agosto de 1955 , n. 848, sotto Il profilo del mancato rispetto del termine ragionevole di cui all'articolo 6 , parágrafo 1 , della Convenzione, há diritto ad una equa riparazione. 
instância cível.

\section{DADOS ESTATÍSTICOS BRASILEIROS}

Com objetivo de demonstrar que a razoável duração do processo ainda é uma realidade distante no Brasil, a tabela1 apresenta o número de entrada e saída de todos os processos de conhecimento no $1^{\circ}$ grau de toda Justiça brasileira. Os dados foram apresentados pelo Conselho Nacional de Justiça (CNJ) no relatório anual “Justiça em números 2014” para o ano 2013.

Tabela 1 - Dados referentes a casos de conhecimento não criminais no $1^{\circ} \mathrm{Grau}^{4}$

\begin{tabular}{lc}
\hline \multicolumn{2}{c}{ PROCESSOS DE CONHECIMENTO NA JUSTICCA BRASILEIRA-2013 } \\
\hline Processos novos de conhecimento no \\
$1^{\circ} \mathrm{Grau}$ não criminais em 2013 \\
$\begin{array}{l}\text { Processos de conhecimento baixados no } \\
1^{\circ} \mathrm{Grau} \text { não criminais em } 2013\end{array}$ \\
$\begin{array}{l}\text { Processos de conhecimento pendentes no } \\
1^{\circ} \mathrm{Grau} \text { não criminais }\end{array}$ \\
\hline
\end{tabular}

Fonte: Conselho Nacional de Justiça (2013).

Embora as publicações do CNJ não tragam o tempo médio para baixa de um processo em primeira instância, nem qualquer equação para o cálculo desse tempo médio, os autores, baseado na Tabela1, apresentam equação para cálculo do tempo médio em dias para baixa de um processo em primeira instância.

\section{Tempo médio $=\left[\frac{\text { Processos novos }+ \text { Process os pendentes }}{\text { Processos baixados }}\right] \times 365$}

Os processos novos, somados aos processos pendentes, expressam a quantidade de processos que ainda devem ser resolvidos. Se dividir-se o resultado dessa soma pelo número de processos baixados e multiplicar pelos 365 dias do ano, o resultado final sugere o tempo médio em dias para baixa de um processo.

Utilizando a equação e os dados publicados na tabela 1, o tempo médio para baixa de processos de conhecimento em primeira instância no Judiciário brasileiro é de 925 dias, o que demonstra que a razoável duração do processo ainda é uma realidade distante na Justiça brasileira, sobretudo quando comparado a países europeus, demostrado no gráfico 1.

4 Os casos novos, baixados e pendentes, referem-se aos de conhecimento de $1^{\circ} \mathrm{Grau}$ não criminais que segundo o CNJ: são processos não criminais de conhecimento, cautelares, mandamentais e ações constitucionais que ingressam e foram protocolizados no Poder Judiciário brasileiro em 2013, excluídos os embargos do devedor, impugnações ao cálculo, cumprimento de títulos judiciais, cartas precatórias e de ordem recebidas e outros procedimentos passíveis de solução por despacho de mero expediente. Ainda, considera-se baixado os processos remetidos a outros órgãos judiciais competentes, remetidos a instâncias superiores, arquivados definitivamente, os que houveram decisão transitada em julgado e iniciou-se a liquidação, cumprimento ou execução. Não se constituem baixas remessas para cumprimento de diligências e as entregas para carga ou vista. 
Gráfico 1- Tempo médio em dias [d] necessário para baixa ${ }^{5}$ de processos de conhecimento cíveis em primeira instância. Comparação entre Brasil e países europeus.

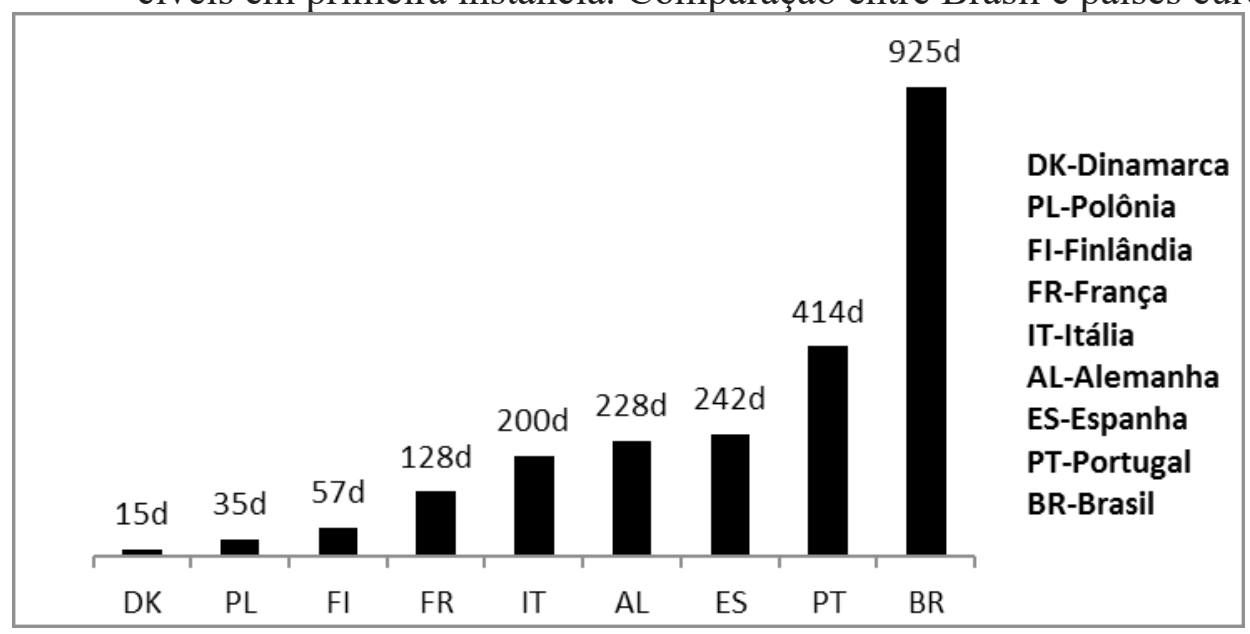

Fonte: Comissão Europeia (2015); Conselho Nacional de Justiça (2013).

$\mathrm{Na}$ "França a média é de 128 dias, Itália 200 dias, Alemanha 220 dias, Espanha 242 dias e em Portugal 414 dias" (COMISSÃO EUROPEIA, 2015). Como se vê, comparado as nações européias, o Brasil encontra-se em péssima situação, com diferença de 511 dias a mais em relação a Portugal, que apresenta o pior resultado dentre os países pesquisados.

\section{ALCANCE DO ARTIGO 37, § $6^{\circ}$., DA CONSTITUIÇÃO E A RESPONSABILIDADE CIVIL DO ESTADO}

Uma primeira interpretação do artigo $37, \S 6^{\circ}$., da Constituição Federal faz surgir dúvidas quanto à responsabilização dos Poderes Legislativo e Judiciário, restringindo a aplicação da teoria do risco administrativo aos atos do Poder Executivo. Para analisar o alcance do artigo, veja-se primeiramente o conceito de serviço público, e se a atividade judiciária deve ser equiparada a ele.

O Professor Hely Lopes Meirelles define serviço público como "todo aquele prestado pela Administração Pública ou por seus delegados, sob normas e controles estatais, para satisfazer necessidades essenciais ou secundárias da coletividade ou simples conveniência do Estado" (MEIRELLES, 1993, p. 290).

Para Maria Sylvia Zanella Di Pietro (1998, p. 90)., "serviço público é toda atividade material que a lei atribui ao Estado para que a exerça diretamente ou por meio de seus delegados, com o objetivo de satisfazer concretamente as necessidades coletivas, sob o regime jurídico total ou parcialmente público"

Percebe-se que, para a autora, o serviço público liga-se às atividades nas três esferas de Poder, devendo então a atividade jurisdicional ser caracterizada como serviço público, eis que é

5 Considera-se baixado os processos remetidos a outros órgãos judiciais competentes, remetidos a instâncias superiores, arquivados definitivamente, os que houveram decisão transitada em julgado e iniciou-se a liquidação, cumprimento ou execução. Não se constituem baixas remessas para cumprimento de diligências e as entregas para carga ou vista. 
uma função essencial e exclusiva do Estado.

Portanto, a prestação jurisdicional integra o serviço público essencial e sua ineficiência pode ser caracterizada como serviço público defeituoso, causando a responsabilidade do Estado.

Analisando aquele dispositivo constitucional, José da Silva Pacheco fornece a interpretação no sentido de que, "tendo sido adotado a expressão serviço público, há que se concebê-la como gênero, de que o serviço administrativo seria mera espécie, abrangendo, desse modo, a atividade função jurisdicional e também a legislativa, e não somente a administrativa do Poder Executivo." (PACHECO, 2010, p. 115).

É certo que, prevendo a Constituição Federal determinado serviço como atribuição específica do Estado, e se entender serviço público como qualquer atividade que tenha como objetivo a tutela do interesse coletivo, pode-se perfeitamente concluir que qualquer atividade dos três Poderes deve ser considerada serviço público e, portanto, no exercício de qualquer uma delas pode eventualmente o Estado provocar danos ao particular.

Assim, a prestação de um serviço público, sobretudo o essencial, deve ser pautada no maior desempenho possível com o menor dispêndio ao erário público, e evidentemente, sendo o Judiciário prestador de um serviço público essencial, estar submetido ao princípio da eficiência. Não se pode olvidar que, estando todos os administradores sujeitos ao princípio da eficiência, os agentes judiciários também devem estar, e com as mesmas responsabilidades dos demais agentes estatais, sendo, inclusive, considerado o magistrado como um agente estatal.

Toda a atividade jurisdicional deve ser considerada como serviço público, cabendo a aplicação do artigo $37, \S 6^{\circ}$., da Constituição Federal, e por isso, caso o serviço defeituoso provoque dano, ensejará responsabilidade. Nesse sentido Sérgio Cavalieri Filho:

[...] já ficou assentado que o arcabouço da responsabilidade estatal está estruturado sobre o princípio da organização e do funcionamento do serviço público. E, sendo a prestação da Justiça um serviço público essencial, tal como os prestados pelo Poder Executivo, não há como e nem se pode querer escusa o Estado de responder pelos decorrentes da negligência judiciária, ou do mau funcionamento (CAVALIERI FILHO, 2004, p. 266).

No caso de morosidade processual, o Estado deve responder objetivamente quando decorrente de deficiência no aparelhamento do Poder Judiciário, ou ainda no caso de culpa ou dolo do magistrado. O Estado deve ser objetivamente responsabilizado mercê da aplicação da teoria do risco administrativo, fundado na atividade, pois se o Estado assumiu para si a função de prestar a tutela jurisdicional, os defeitos e falhas só podem ser reparados pelo próprio Estado, e em havendo culpa ou dolo do agente, o Estado poderá responsabilizá-lo regressivamente, aplicando-se a teoria subjetiva, conforme determina a Constituição. Resumidamente, na relação Estado/terceiro aplicase a teoria objetiva, e para Estado/agente a teoria subjetiva.

Vários doutrinadores defendem que o Estado deve ser responsabilizado objetivamente, inclusive devendo a indenização ser estendida a terceiro interessado. 
Para Paulo Hoffman:

Diante do novo inciso LXXVIII do art. $5^{\circ} \mathrm{da} \mathrm{CF}$, com a previsão da duração razoável do processo como garantia constitucional do cidadão, nosso posicionamento é cristalino no sentido de que o Estado é responsável objetivamente pela exagerada duração do processo, motivada por dolo ou culpa do Juiz, bem como por ineficiência da estrutura do Poder Judiciário, devendo indenizar o jurisdicionado prejudicado - autor, réu, interveniente ou terceiro interessado- independentemente de sair-se vencedor ou não da demanda, pelos prejuízos materiais e morais (HOFFMAN, 2012, p. 207).

Há na literatura doutrinadores que defendem a responsabilidade subjetiva do Estado quando da demora processual, sob o argumento de que deve evitar-se que o Estado seja responsabilizado arbitrariamente pela demora para a qual não concorreu. $\mathrm{O}$ argumento não se sustenta, porque o desatendimento dos prazos processuais, notadamente por carência de pessoal e estrutura, é responsabilidade imputada ao próprio Estado.

Por outro lado, há doutrinadores que defendem a parcial responsabilização do Estado.

Araken de Assis chama a atenção para reflexão se o Estado é o único responsável pela delonga processual, questionado se este deve responder sozinho, pois o comportamento das partes certamente influi na celeridade processual.

Não pode surpreender a ninguém a principal conclusão dos primeiros ensaios acerca do direito fundamental à duração razoável do processo. Atribui-se ao Estado, unanimemente, responsabilidade civil e o lesado a pretensão a reparar o dano. Indubitável que seja a consequência - e, naturalmente, o assunto reclama maior ponderação-, não deixa de contradizer o referido direito; dificilmente as demandas dos incontáveis prejudicados contribuirão com a diminuição do número de feitos e, portanto, com a brevidade para os demais processos pendentes (ASSIS, 2012, p. 207).

Admitindo que a parte litigue com abuso processual, deve esta indenizar, e consequentemente a indenização do Estado restará mitigada.

\subsection{Teses contrárias à responsabilidade do estado por atos jurisdicionais}

As principais teses contrárias à responsabilização do Estado que merecem ser analisadas são: a) a atividade judiciária não é serviço público; b) a soberania do Poder Judiciário; c) a independência da magistratura; d) a ausência de texto legal; e) a incontrastabilidade da coisa julgada.

A primeira tese já foi aqui tratada, ficando verificado, a nosso ver, que a atividade judiciária deve ser considerada como serviço público. Vejam-se as demais. 


\section{a) A soberania do Poder Judiciário}

Uma das principais correntes doutrinárias é a da irresponsabilidade estatal por atos do Poder judiciário. Por essa tese, o Poder Judiciário é soberano, e por isso não é admitida a responsabilidade de nenhum de seus agentes. Esta tese, já superada, não tem como subsistir, pois a soberania não é privilégio do Judiciário, mas sim do próprio Estado. Como ensina Cavalieri Filho:

[...] além da imprecisão do vocábulo "soberania", e da polêmica existente em torno do seu sentido, como considerar o Judiciário um poder soberano sem situar no mesmo patamar os outros dois poderes? O Judiciário não é um superpoder colocado sobre os outros (CAVALIERI FILHO, 2004, p. 261).

A soberania é atributo do Estado e não de seus Poderes. Os três Poderes "agem no desempenho da soberania do Estado, não sendo isoladamente soberanos, aparecendo nítida nas relações externas com outros Estados" (DI PIETRO, 2004, p. 558).

A ideia da soberania dos Poderes com base na soberania estatal é totalmente ultrapassada, haja vista que, se fosse aplicada, deveria ser da mesma maneira nos três Poderes, face ao princípio da isonomia.

\section{b) A independência da magistratura}

Não se questiona que a independência dos magistrados seja essencial na aplicação da Justiça. Entretanto, a independência do juiz não foi criada para deixá-lo isento de responsabilidade, mas tão-somente para que suas decisões sejam livres e isentas de coação em qualquer ordem.

A independência do magistrado pode ser vista na esfera política e jurídica. "Na esfera política resguarda seu julgamento da influência dos demais Poderes sob a ótica da inamovibilidade, irredutibilidade e vitaliciedade, ao passo que a jurídica atinge o exercício de suas funções baseado na lei e nos princípios gerais do direito" (CAVALIERI FILHO, 2004, p. 289).

Ainda, o magistrado deve ser considerado agente público, pois exerce um cargo criado por lei e subordina-se administrativamente ao Poder Judiciário. Contudo, é correto afirmar que se o magistrado não agir com culpa ou dolo e observar os prazos processuais estabelecidos, não há que se falar em responsabilidade pessoal.

Já, em caso de dano causado por culpa impessoal do serviço público ou atuação irregular dos serventuários da Justiça ou mesmo do magistrado que caracterizem a demora processual, aplica-se o artigo 37, § $6^{\circ}$., da Constituição Federal.

\section{c) A ausência de texto legal}

$\mathrm{O}$ argumento de ausência de texto legal parte da tese do "Il n'y a pás de responsabilité sans texte", adotada por Tribunais franceses no início do século XX, há muito foi abandonada.

Sobre o tema, Celso Antônio Bandeira de Mello afirma "não crer que possa, no moderno Estado de Direito, colocar qualquer dúvida sobre a existência do princípio da responsabilidade do Estado nos casos em que falte texto expresso dispondo sobre a matéria" (MELLO, 2003, p. 859). 
O que se deve observar é que aquela norma é autoaplicável, possuindo eficácia plena para todas as atividades judiciais danosas, incluindo a morosidade processual. A responsabilidade estatal é a regra e não a exceção. O que deveria estar expresso em lei são os casos de não aplicação da responsabilidade estatal, e não o contrario.

\section{d) A incontrastabilidade da coisa julgada}

Incontrastabilidade é sinônimo daquilo que não se pode superar, anular.

Com essa afirmação era defendida a irresponsabilidade do Estado, porque a coisa julgada atingiria a condição de verdade incontestável.

Contudo, o argumento não procede, pois a responsabilização do Estado pela prestação tardia, nenhuma mudança causa no conteúdo da coisa julgada, agora imutável. Todavia, se a demora causar dano ao jurisdicionado, nada mais justo que o Estado seja responsabilizado, pois não é possível imaginar que o instituto da coisa julgada possa excluir liminarmente a responsabilização estatal.

Portanto, a coisa julgada é resultado das decisões judiciais, sendo ato destinado à pacificação social, não podendo, por outro lado, limitar a responsabilidade do Estado quando estes mesmos atos, de maneira tardia, causem dano à parte, pois um dos motivos pelos quais o Estado foi criado é a pacificação social e não o direito incontestável de promovê-la tardiamente.

\subsection{O argumento da carência de recursos e excesso de demanda}

A carência de recursos humanos e materiais no Judiciário é apontada como um dos principais argumentos justificadores da impossibilidade de aplicação do mandamento da duração razoável do processo.

Frederico Augusto koehler defende posição contrária ao afirmar que:

Parte da doutrina sustenta que a ausência de recursos públicos faz com que existam limites reais, e por isso entrará em cena a ideia da reserva do possível como excludente de responsabilidade do Estado. Contudo, a administração Pública está obrigada a garantir a tutela jurisdicional com a rapidez que permita a duração razoável dos processos, ainda quando a dilação se deva a carências estruturais da organização judicial, pois não é possível restringir o alcance de seu conteúdo deste direito, dado o lugar que a reta e eficaz prestação jurisdicional ocupa em uma sociedade democrática. A consideração da insuficiência dos meios disponíveis ou o imenso volume de trabalho que pesa sobre determinados órgãos judiciais pode isentar juízes pelos atrasos, mas não priva o cidadão de reagir frente a tal demora, nem permite considerá-la inexistente (KOEHLER, 2013, p. $133)$.

A carência de recursos não justifica e nem exclui a responsabilidade do Estado, pois a celeridade deve ser vista como garantidora da aplicação dos demais direitos fundamentais quando perseguidos em Juízo. A carência da estrutura judiciária não pode ser alegada como justificativa 
para a morosidade, o que significaria a violação do próprio conteúdo essencial do direito, ou seja, um processo em tempo razoável.

\section{CONCLUSÃO}

Não são novos os debates acerca da morosidade processual. Trata-se de fenômeno antigo em vários ordenamentos jurídicos. No entanto, a morosidade processual atingiu no Brasil padrões impossíveis de ser tolerados, sobretudo por aqueles que necessitam de urgência na resposta do Estado. O tempo médio para baixa em $1^{\mathrm{a}}$. instância de um processo de conhecimento no Judiciário brasileiro é de 2,53 anos.

Ainda não há conceito definitivo sobre a razoável duração do processo. Um dos "melhores" critérios para verificação do que seria razoável é utilizado pela Corte Europeia de Direitos Humanos, sendo tais critérios utilizados em diversas Cortes Supremas da Europa. Países como Argentina, Espanha e Itália promoveram avanços em reconhecer o direito à prestação jurisdicional sem dilações indevidas. Essa evolução fica mais evidente quando editada lei infraconstitucional, como no caso da Itália.

As teorias que defendem a irresponsabilidade estatal: a) soberania do Poder Judiciário; b) independência da magistratura; c) ausência de texto legal; d) incontrastabilidade da coisa julgada; não são suficientes para eximir o Estado de responsabilidade, pois nenhuma é capaz de superar a incontestável verdade de que o Poder Judiciário é prestador de serviço público, não podendo eximir-se do artigo 37, §,6 $6^{\circ}$, da Constituição Federal.

$\mathrm{O}$ argumento da carência de recursos e excesso de demanda só demonstra a prestação defeituosa do serviço, servindo apenas para isentar a responsabilidade pessoal do magistrado, mas não a do Estado.

\section{REFERÊNCIAS}

ANNONI, Danielle. O direito humano de acesso à Justiça em um prazo razoável. 2006. Tese (Doutorado em Direito) - Universidade Federal de Santa Catarina, Florianópolis, 2006.

ASSIS, Araken. Duração razoável do processo e reformas da lei processual. In: JOBIM, Marcos Félix. O direito a razoável duração do processo: responsabilidade civil do Estado em decorrência da intempestividade processual. 2. ed. Porto Alegre: Livraria do Advogado, 2012.

BRASIL. [Constituição (1988)]. Constituição da República Federativa do Brasil de 1988. Brasília, DF: Presidência da República, 1988. Disponível em: http://www.planalto.gov.br/ ccivil_03/constituicao/constituicao.htm. Acesso em: 9 jun. 2017.

BRASIL. Superior Tribunal de Justiça (1 Turma). Recurso Especial 714.710/MG. Relator: Ministro Herman Benjamin. Brasília, DF, 06 de mar. de 2007. Diário da Justiça Eletrônico, 7 fev. 2008. Disponível em: http://www.stj.jus.br/SCON/. Acesso em: 9 jun. 2017.

BRASIL. Supremo Tribunal Federal (1 Turma). Recurso Ordinário em Habeas Corpus 
123925. Relator: Ministro(a) Rosa Weber. Brasília, DF, 23 de mar. de 2015. Diário da Justiça Eletrônico, 14 abr. 2015. Disponível em: http://www.stf.jus.br/portal/jurisprudencia. Acesso em: 26 jun. 2017.

CÂMARA DOS DEPUTADOS. Exposição de motivos n²04/2004: Pacto de Estado em favor de um Judiciário mais rápido e republicano. Brasília, DF: Câmaras dos Deputados, 2004. Disponível em: http://www2.camara.leg.br. Acesso em: 22 jun. 2017.

CÂMERA, Alexandre Freitas. Lições de direito processual civil. 16. ed. Rio de Janeiro: Lumen Juris, 2007. v.1. In: JOBIM, Marcos Félix. O direito a razoável duração do processo: responsabilidade civil do Estado em decorrência da intempestividade processual. 2. ed. rev. amp. Porto Alegre: Livraria do Advogado, 2012. p. 61.

CAVALIERI FILHO, Sérgio. Programa de responsabilidade civil. 5.ed. São Paulo: Malheiros, 2004.

COMISSÃO EUROPÉIA. Effective justice. Bruxelas, abr. 2015. Disponível em: http:// ec.europa.eu/justice/effective-justice/files/justice_scoreboard_2015_pt.pdf. Acesso em: 12 jun. 2017.

CONSELHO NACIONAL DE JUSTIÇA (Brasil). Justiça em números 2013. Brasília: CNJ, 2013. p. 300. Disponível em: http://www.cnj.jus.br/images/pesquisas-judiciarias/Publicacoes/ relatorio_jn2013.pdf. Acesso em: 26 jun. 2017.

DALMOTTO, Eugenio. Diritto all'equariparazione per l'eccessiva durata del processo. In: CHIARLONI, Sergio. Misure acceleratorie e riparatori e contro l'irragionevole durata dei processi. Torino: Giappichelli, 2002. p.173-174.

DERGINT, Augusto do Amaral. Responsabilidade do Estado por atos jurisdicionais. São Paulo: Revista dos Tribunais, 1994. p. 12.

DI PIETRO, Maria Sylvia Zanella. Direito administrativo. 9. ed. São Paulo: Atlas, 1998. p. 90.

DI PIETRO. Maria Sylvia Zanella Direito administrativo. 17. ed. São Paulo: Atlas, 2004.

ESPANHA. Constitución Española de 1978. Disponível em: http://www.congreso.es/consti/. Acesso em: 17 jun. 2017.

ESPANHA. Tribunal Constitucional. Recurso de Amparo 3.685-1994. Sentencia 180/1996 de 12 nov. de 1996. Boletín Oficial del Estado, Madri, ES, n. 303, 17 dez. 1996. Disponível: http:// wwww.hj.tribunalconstitucional.es. Acesso em: 17 jun. 2017.

ESPANHA. Tribunal Constitucional. Recurso de amparo 5727-2010. Sentencia 99/2014.

Boletín Oficial del Estado, Madri, ES, n. 177, 22 jul. 2014. Disponível em: htpp:// hj.tribunalconstitucional.es. Acesso em: 17 jun. 2017.

FERREIRA, Camille Gonçalves Javarine. Razoável duração do processo e responsabilidade civil do Estado. 2013. Monografia (Especialização) - Escola da Magistratura do Estado do Rio de Janeiro, Rio de Janeiro, 2013.

HOFFMAN, Paulo. Razoável duração do processo. São Paulo: QuartierLatin, 2006. In: JOBIM, 
Marcos Félix. O direito a razoável duração do processo: responsabilidade civil do Estado em decorrência da intempestividade processual. 2. ed. Porto Alegre: Livraria do Advogado, 2012. p. 99.

ITÁLIA. Legge Pinto. Lei n. 89 di 24 mar. 2001. Previsione di équa riparazione in caso di violazione del termine ragionevole del termine ragionevole del processo e modifica dell'articolo 375 de códice di procedura civile. G.U., Roma, 3 abr. 2001. Disponível em: http://www.gov.it. Acesso em: 23 jun. 2017.

JOBIM, Marcos Félix. O direito a razoável duração do processo: responsabilidade civil do Estado em decorrência da intempestividade processual. 2. ed. Porto Alegre: Livraria do Advogado, 2012. p. 35.

KOEHLER, Frederico Augusto Leopoldino. A razoável duração do processo. 2.ed. Salvador: Editora JusPodivm, 2013.

MARINONI, Luiz Guilherme. Abuso de defesa e parte incontroversa da demanda. São Paulo: Revista dos Tribunais, 2007.

MEIRELLES, Hely Lopes. Direito administrativo. 18. ed. São Paulo: Malheiros, 1993.

MELLO, Celso Antônio Bandeira de. Curso de direito administrativa. 17. ed. rev. atual. São Paulo: Malheiros, 2003.

MOREIRA, José Carlos Barbosa. Temas de direito processual. São Paulo: Saraiva, 2001.

PACHECO, José da Silva. A nova Constituição e o problema da responsabilidade civil das pessoas jurídicas de direito público e privado prestadoras de serviço público. São Paulo: Revista dos Tribunais, 2010.

SCABORA, Casellato Filipe. Responsabilidade civil do Estado e a morosidade processual. Revista de direito dos monitores da Universidade Federal Fluminense, Rio de Janeiro, ano 4, n.10, p. 1 - 40, abr. 2011.

VALENTE, Rachel Soares. Responsabilidade civil do Estado por violação ao direito à razoável duração do processo. 2008. Monografia (Especialização) - Universidade Cândido Mendes, Rio de Janeiro, 2008.

VIANA, Adriana Grandinetti. A razoável duração do processo como mecanismo de desenvolvimento social. 2007. Dissertação (Mestrado em Direito) - Pontifícia Universidade Católica do Paraná, Curitiba, 2007.

Como citar: MARQUESI, Roberto Wagner; BONTEMPI, Alessandro. Morosidade processual e a responsabilidade civil do estado. Revista do Direito Público, Londrina, v. 14, n. 1, p. 139-159, abr. 2019. DOI: 10.5433/1980-511X2019v14n1p139. ISSN: 1980-511X.

Recebido em: 15/07/2017.

Aprovado em: 13/02/2019. 